\title{
実践研究
}

\section{生態学的調査にもとづく知的障害のある児童の 買い物スキルの形成}

\author{
横 山 英 美*・村 中 智 彦**
}

\begin{abstract}
本研究では、2 名の知的障害のある児童を対象に、社会的比較による生態学的調査にもと づいて、母親の同行による買い物スキルを形成した。参加児の標的行動に作用した要因と参 加児の変容、標的行動選定の手続きの観点と妥当性について検討した。参加児は知的障害の ある 10 歳女児と 8 歳男児の 2 名であった。買い物スキルを促進するための介入は、地域店舗 で行われた。介入前に、参加児と同年代の他児の買い物行動の生態学的調查を行った。女児 では 13 項目の買い物行動が、男児では 17 項目が標的とされた。女児では介入 (1) (3)、男児 では介入 (1)〜 (4)、両者でフォローアップを行った。介入 (1)〜 (4)のそれぞれで、標的行動は 段階的に実行された。介入の結果、標的行動の導入後すぐに、またはセッションの後半にな ると自発遂行が増加した。生態学的調査にもとづく介入によって、参加児の未経験の標的行 動を形成できることが示唆された。参加児がすでに有するスキルを買い物行動にすることで 母親が成功体験を得る可能性を示唆した。
\end{abstract}

キー・ワード：生態学的調査 買い物スキル 知的障害

\section{I . 問題と目的}

知的障害があっても、多様なスキルを身に付ける ことで、地域の中で自立した生活を営むことはでき る。知的障害のある子どもの生活スキルの形成を試 みる研究は 1980 年代から発表され、店舗での買い物 (Morse, Schuster, \& Sandknop, 1996; 菅野 ・羽鳥・井 上・小林, 1995; 嶋田・清水・氏森, 1998; 渡部・山口 · 上松・小林, 1999; 渡部・山本・小林, 1990; 依田・清 水・氏森, 1996)、バスや電車による移動（安部, 1997）、 携帯電話の利用（福永・大久保・井上, 2005）といつ たさまざまなスキルが報告されている。これらは従来 サバイバルスキルとして位置づけられていたが（渡部 ら, 1990)、近年では、人が生きていくために必要で自 立を促すライフスキル（life skills）という広範な概念 が提起され、本研究のテーマとなる買い物スキルは食 生活や家事遂行の指導領域に位置づけられている（小 貫, 2009)。買い物は子どもにとって日常場面での機 会が多く、身近な活動のひとつであろう。毎日の生活 必需品の購入だけでなく、欲求や好みにもとづいて商

$*$ 新潟県立小出特別支援学校

** 上越教育大学臨床 健康教育学系
品を選択する、支払い時に計算スキルを学ぶ、余㗇と してウインドーショッピングを楽しむといった経験 は、従業員や地域の人との相互交涉の機会にもなる (Morse et al., 1996; 渡部ら, 1990)。

Morse et al. (1996) は、1980〜1995 年に発表された 買い物スキルを扱った研究 20 編をレビューし、参加 者の年齢段階では 16 歳以上が $60 \%$ を占めるが、学齢 期から成人期まで幅広く、知的障害の程度も中度から 最重度まで広範であったことを報告しており、わが国 の研究でも同様の傾向が認められる。そして、いずれ の年齢段階や知的障害の程度でも、参加児が一人で買 い物をする実態が想定されている（神山・野呂, 2010; Morse et al., 1996; 菅野ら, 1995; 渡部ら, 1999; 渡部ら, 1990; 依田ら, 1996)。障害児と家族の生活状況調查報 告書では、障害児の $82.3 \%$ で家族等が同行し、援助が 必要であったとの実態が報告されており（横浜市こど も青少年局横浜障害児を守る連絡協議会, 2011)、参加 児が一人で店舗に出向き自力で買い物するだけでな く、家族の同行、つまり援助付きの参加を想定したス キル形成を促す手続きの検討も必要であろう。参加児 の居住地域や交通事情にも左右されるが、援助付きの 買い物スキルを形成することで、日常場面での参加機 
会やその質は拡大しやすくなると考えられる。

先行研究で多用される手続きとして、買い物行動の 課題分析による行動連鎖の形成、そのための段階的プ ロンプト法の活用がある（Morse et al., 1996; 渡部ら, 1999; 渡部ら , 1990)。ただし、課題分析では、一般的 な成人の買い物行動が標的とされ、家族の同行を想定 し、参加児個々の生活スタイルに適合したものとはい いがたい。参加児の生活スタイルにもとづく標的行動 を選定する手続きとして、生態学的調查 (ecological inventory）が挙げられる。生態学的調査とは、対象と なる事物に人工的な手を加えず現象そのままを叙述す る調査であり、日常場面で実施可能かつ実用的な標的 行動や手続きが選定できる（加藤, 1997）。根拠にもと づく支援方法の選択決定が重視される現在、こうした 調査結果に即して標的行動を選定する手続きは欠かせ ないであろう。指導対象となる標的行動が社会的にど れだけ重要であるのかという社会的妥当性を査定する 方法のひとつに、社会的比較 (social comparison) が ある。社会的比較とは、障害のある子ども本人の生活 の質の向上を目指した指導の到達目標について、同年 歯の子どもの行動を参考にして選定する手続きである (野呂, 1996)。社会的比較にもとづくと、生態学的調 査の対象は参加児本人と家族、加えて同年代 - 同地域 （以下、同年代）の子どもたちの買い物行動となる。し かし、先行研究では参加児と家族を対象とする実態調 査が中心で、同年代の子どもの買い物の実態は調べら れていない。支援対象となる参加児と家族のニーズを 踏まえた実態調査は大切であるが、当該児の買い物機 会が乏しい場合、ニーズそのものが低かったり育って いなかったりする状況が推測される。参加児と同年代 の子どもが店舗でどのように買い物をしているかを調 べることで、本人と家族のニーズを超えた標的行動の 設定やその広がりが期待できると予測される。

参加児が家族と同行するにしても、標的となる買い 物行動は多様にある。「どの買い物行動を優先し、ど ういった順番で形成するのか」といった適切な標的行 動選定の観点と手順を明らかにしなければ、実践に向 けた応用可能性の広がりは見込めない。先行研究では 選定の観点として、参加児の生活年齢に合っている か、参加児の好みや生活年齢に即しているか、参加 児が実行できるスキルかなどが示されており（岩嶋, 2008; 神山・野呂, 2010; 太田, 2014; 竹井 - 五味 - 野呂, 2009; 渡部ら, 1999)、こうした観点のうちどれが要点 となるのかの検証が求められる。神山・野呂 (2010) は、特に生活者である家族の支援に要する負担に配慮
する重要性を指摘している。介入では、家族の負担を 軽減するために、一度にたくさんの標的行動への支援 を求めるのではなく、段階的に導入する手続きが必要 であろう。

本研究では、知的障害のある児童 2 名の買い物スキ ルの形成において、生態学的調査にもとづき、家族と の同行を想定した標的行動を選定し、介入において段 階的に導入した。実践を通じて、生態学的調査にもと づく買い物行動の形成と参加児の変容、標的行動選定 の観点と手順の妥当性について明らかにすることを目 的とした。

\section{II. 方 法}

\section{1. 参加児と倫理的配慮}

2 名の参加児 (participant; 以下、P) の母親に研究協 力を依頼し、同意を得た。2名とも、第二著者が主催 する大学での指導に 3 年以上の参加経験を有してい た。参加児を年齢の高い順に P1、P2 とした。P1 は小 学 4 年生 (10 歳) の女児で、知的障害特別支援学級に 在籍していた。ダウン症と診断されていた。家族構成 は父、母、P1、小学 1 年生の妹の 4 名であった。発音 不明膫であったが、聞き手に伝わらないと身振りで伝 えたり言い直したりした。五十音すべての平仮名やカ タカナの読み書き、簡単な加減の計算ができた。研究 開始時の買い物では、休日に母親が買い物に誘うと同 行した。店舗では自らかごを持ち運んだが、かごが重 たくなると母親に手渡した。会計や袋詰めでは母親の そばで見ていた。母親は、買い物カート（以下、カー ト）について、押すことはできるが人や商品にぶつか ることがあるため使用しないと報告した。新版 S-M 社 会生活能力検査では、CA $10 ： 1$ 、社会生活年齢 $(\mathrm{SA})$ $5: 10$ 、社会生活指数 $(\mathrm{SQ}) 58$ 、身辺自立 $8: 6$ 、移動 $2: 11$ 、作業 $5: 10$ 、意思交換 $4: 9$ 、集団活動 $7: 3$ 、 自己統制 $6: 10$ であった。

$\mathrm{P} 2$ は小学 3 年生（8 歳）の男児で、知的障害特別支 援学級に在籍していた。運動精神発達遅滞と診断さ 机ていた。家族構成は父、母、小学 5 年生の兄、P2の 4 名であった。ボタンやファスナーなどの指先を使っ た細かな動作に困難があり、介助を必要とした。話し 言葉で自ら意思を伝えるが、P1に比べて働きかけの レパートリーはそしく、適切な応答も困難であった。 部分的に平仮名やカタカナの拾い読みができた。買い 物では、母親が誘っても、自宅や車中で携帯型ゲーム をして過ごすことが多かった。同行すると、目につい た商品を手に取ってカートに入れた。店内では、P2が 
好きなブロックの玩具を持ち、目の前でいじる感覚 遊びに従事し、母親に付いて歩くだけであった。新版 S-M 社会生活能力検査では、CA $8: 9 、 S A ~ 4: 3 、 S Q$ 48、身辺自立 $3: 0$ 、移動 $4: 8$ 、作業 $4: 5$ 、意思交換 $4: 9$ 、集団活動 $4: 9$ 、自己統制 $5: 8$ であった。P1に 比べて SA、SQの值は低かった。

倫理的配慮として、母親に対して研究目的、観察・ 記録方法、予想される成果、個人情報の守秘義務の遵 守、協力の中断や辞退の自由を明記した文書で協力を 依頼した。途中経過や研究終了後、母親への中間およ び最終報告会を計 3 回実施した。著者が所属する大学 の研究倫理審査委員会から承認を得た。

\section{2. 介入期間および場所、研究者の役割}

期間は $\mathrm{X}$ 年 4 月〜 $\mathrm{X}+1$ 年 1 月の 10 か月であった。 支援の場所は参加児と家族 (P1、P2 ともに実態調査 より母親）が普段利用する店舗で、観察、介入および フォローアップのすべてを実施した。利用店舗は、 P1、P2 ともに、地域密着型の食料品や日用品を販売 するスーパーマーケットで、P1 は I 店、 $\mathrm{P} 2$ は $\mathrm{N}$ 店で あった。第一著者（以下、支援者）は、母親と参加児 に同行して観察記録を行い、介入計画を立案した。店 舗での参加児への支援は、介入手続きにもとづいて母 親が主として行ったが、支援者も必要に応じて参加児 への補助的支援を行った。母親との支援に関する打ち 合わせは、月 1 回のペースで、大学か自宅で行った。

\section{3. 買い物の調査}

（1）参加児の実態調查：介入前の買い物に関す る実態を調査した。先行研究 (菅野ら, 1995; 渡部ら, 1999）の質問項目を参照し、母親に対して買い物の日 時、利用店舗、同行者の有無、参加児の買い物経験、 指導への要望を聞き取った。同時に、支援者が参加児 と母親の買い物に同行し、その様子を直接観察した (P1 で 4 回、P2 で 6 回)。支援者は、店舗の駐車場か ら買い物後に再び乗車するまで 2 ～ 3 メートル後方か ら観察し、事象記録法（原野, 1997）により、母親の 買い物行動や参加児への働きかけ、参加児の店舗での 言動を時系列に記録した。店舗責任者 (以下、責任者) に撮影許可を得てビデオ記録を行った。ビデオ録画よ り筆記記録の正確性を確認した。

実態調査の結果、P1の母親は週 4〜6 回のペースで 曜日に関係なく日中に買い物をしていた。P1が一人 で店舗へ出向く経験はなかった。母親に同行すると P1 は自発的にかごを持ち、レジで小銭を受け取り支 払うこともあった。カートの使用はなかった。母親の 指さした商品を取ってかごに入れることがあった。母
親のそばでエコバッグに商品を詰める様子を見てい た。エコバッグを手渡され車に運ぶことが 1 回あつ た。P2の母親は週に 3 回のペースで平日の日中に買い 物をしていた。P1 と同様に、P2 が一人で店舗へ出向 く経験はなかった。母親に同行すると、P2 はブロック の玩具を目の前でいじって遊びながら母親に付いて歩 いた。母親はカートを使用していたが、P2が押すこと はなかった。支払い後、母親から「お手伝い」と頼ま れ、レジ袋を持つことが 1 回あったが、車に運ぶ前に 途中でやめた。

（2）一般客の生態学的調查：社会的比較の手続 きにより、参加児と同年代の子どもが店舗でどのよう

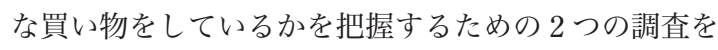
実施した。まず、I店、N 店で、一般客を対象とする 調查を行った。責任者に許可を得て、幼児あるいは小 学生と推測される子どもと家族を対象に、店内での買 い物の様子を直接観察した。支援者が出入口付近、菓 子売り場などの 5 か所を定め、10 分ごとに移動して定 点観察した。一般客のプライバシーを保護し、買い物 に支障を来さないように、スマートフォンのメモ機能 を用いて筆記記録した。I店、 $\mathrm{N}$ 店それぞれ平日と休 日に 1 時間ずつ、計 2 回実施した。その結果、I店で 33 名、 $\mathrm{N}$ 店で 30 名の子どもの買い物行動が観察され た。2 店舗に共通して、出入口付近で、家庭から持参 した資源ごみを回収ボックスに入れる行動が多く認め られた。入店後に、かごをカートに置く、カートを押 す行動が多かった。売り場では、子どもが商品を取っ て母親の押すカートに入れる行動が認められた。レジ では、母親から必要な現金を受け取り支払う行動が 2 名で観察されたが、多くの場合、親が現金（もしく はカード）で支払っていた。会計後、子どもが商品を エコバッグ (もしくはレジ袋) に詰めたり持ったりす る行動が多かった。

次に、支援者の大学関係者で、小学 4 年女児と小学 5 年男児がいる 2 組の親子を対象に、普段の買い物の 様子を直接観察した。母親には「いつもお子さんと買 い物へ行くときと同じように買い物をしてください とお願いし、自宅近くの店舗で買い物をしてもらつ た。観察や記録は実態調査と同じであった。母親には 観察終了後に結果を報告した。

その結果、小学 4 年女児の親子では、入店まで母親 と手をつなぐが、店内では母親と別行動で、子どもは 一人で雑誌を見る行動が観察された。母親のそばにい るときにはカートを押した。レジ付近で母親に買い忘 れの商品を取ってくるように頼まれ、一人で取りに行 
Table 1 評価の観点と段階

\begin{tabular}{|c|c|c|}
\hline & 評価の観点 & 段 階 \\
\hline \multirow{5}{*}{$\begin{array}{l}\text { 参 } \\
\text { 妿 } \\
\text { 児 } \\
\text { に } \\
\text { 関 } \\
\text { す } \\
\text { る } \\
\text { こ } \\
\text { と }\end{array}$} & 1）参加児の生活年齢に合っているか & $\begin{array}{ll}\mathrm{A} & \text { 合っている } \\
\mathrm{B} & \text { 少し合っている } \\
\mathrm{C} & \text { 合っていない }\end{array}$ \\
\hline & 2）参加児の興味、関心に合っているか & $\begin{array}{ll}\mathrm{A} & \text { 合っている } \\
\mathrm{B} & \text { 少しあっている } \\
\mathrm{C} & \text { 合っていない }\end{array}$ \\
\hline & 3）参加児が実行できるスキルか & $\begin{array}{ll}\mathrm{A} & \text { 実行できる } \\
\mathrm{B} & \text { 少し実行できる } \\
\mathrm{C} & \text { 実行できない }\end{array}$ \\
\hline & 4）参加児がその行動をするために母親の援助は必要か & $\begin{array}{ll}\mathrm{A} & \text { 援助が必要ない } \\
\mathrm{B} & \text { 少しの援助が必要である } \\
\mathrm{C} & \text { 多くの援助が必要である }\end{array}$ \\
\hline & 5）スキル獲得後、そのスキルを実施する機会があるか & $\begin{array}{ll}\mathrm{A} & \text { 多くの機会がある } \\
\mathrm{B} & \text { 少しの機会がある } \\
\mathrm{C} & \text { 機会がない }\end{array}$ \\
\hline \multirow{3}{*}{$\begin{array}{l}\text { 親 } \\
\text { に } \\
\text { 関 } \\
\text { す } \\
\text { る } \\
\text { こ } \\
\text { と }\end{array}$} & 6）母親の指導ニーズがあるか & $\begin{array}{ll}\mathrm{A} & \text { 高いニーズがある } \\
\mathrm{B} & \text { 低いニーズがある } \\
\mathrm{C} & \text { ニーズがない }\end{array}$ \\
\hline & 7）母親の支援の負担があるか & $\begin{array}{ll}\mathrm{A} & \text { 負担がない } \\
\mathrm{B} & \text { 少しの負担がある } \\
\mathrm{C} & \text { 多くの負担がある }\end{array}$ \\
\hline & 8）母親は参加児のスキル獲得によって助けられるか & $\begin{array}{ll}\mathrm{A} & \text { 大いに助けられる } \\
\mathrm{B} & \text { 少し助けられる } \\
\mathrm{C} & \text { 助けられない }\end{array}$ \\
\hline
\end{tabular}

1), 2), 3), 4), 6), 7) は, 岩嶋 (2008), 神山・野呂 (2010), 太田 (2014), 嶋田ら (1998), 竹井ら (2009)，渡部ら（1999），依田ら（1996）を参考にした。

く行動が認められた。小学 5 年男児の親子では、子ど もと母親が一緒に行動し、母親に「○○(商品名) を 取ってきて」と頼まれ、その商品の色や個数を口頭で 確認して商品を取っていた。レジでは従業員から釣銭 を受け取り、母親に渡した。エコバッグを自ら持って 車に運んでいた。

\section{4. 標的行動の選定}

参加児の実態調査と生態学的調査から抽出された買 い物行動について、出入口付近、売り場、レジの 3 か 所、P1ではI店に併設されたパン専門店を加えた 4 か 所で振り分けた。P1 では 72 項目、P2 では 56 項目の 標的行動の候補が抽出された。介入で導入する標的行 動を選定するため、買い物や家庭支援をテーマとする 先行研究をもとに、また一部は著者らの協議より、 Table 1のように 1)〜8）の評価の観点と段階を設定 した。例えば、Table 1 の評価の観点「1）参加児の生
活年齢に合っているか」では、神山・野呂（2010）と 太田（2014）をもとに、また5）と 8）の観点は著者 らが設定した。Table 1 の観点 1)～5）は参加児に関す ること、6)～8）は母親に関することで、3 段階によっ て評価した。2，3）４＜wide>，5），7），8）の観点では母親 の負担を考慮し、実態調査をもとに支援者が判断でき る項目は事前に評価し、判断できないものは母親に聞 き取った。 $\mathrm{A}$ を 2 点、 $\mathrm{B}$ を 1 点、 $\mathrm{C}$ を 0 点と得点化し、 合計点で 10 点以上（16 点満点）の標的行動を選定し た。母親と相談しながら、生態学的調査の結果から同 年代の子どもに頻繁に観察された行動のうち、参加児 が遂行可能と思われる項目を加えて標的行動を選定し た。その結果、P1 で 13 項目、P 2 で 17 項目の標的行 動に絞り込んだ。

5. 介入 (1)〜 (4) とフォローアップの手続き

P1 の 13 項目、P2 の 17 項目について、支援者とな 
る母親の負担を配慮し、売り場内やレジなどの場面ご とに標的行動を順次導入する計画を立案した。P1で 介入 (1)〜 (3)、P2で介入 (1)〜 (4)の介入フェイズを設定 した。店舗での 1 回の観察または支援を 1 セッション として、P1で計 21 セッション、P2 で計 22 セッショ ンを実施した。介入 (1)の前に、普段参加児と母親が 実行していた手続きのままで介入 (1) から導入予定の 標的行動の生起を観察する期間 (ベースライン;以 下、BL) を設けた。BLでは、P1で 5 セッション、P2 で 7 セッションを観察記録した。最初の介入 (1)では、 標的行動が生じやすく母親の支援に伴う成功体験が得 られやすいように、「実態調査で参加児に数回観察さ れた」「母親の買い物スタイルに近い」「参加児が容易 にできそう」「その行動を参加児が遂行することで母 親が助けられる」の 4 点を重視し、多く当てはまる行 動を優先的に導入した。具体的には、P1の介入 (1)で は「かごをレジ台からサッカー台へ移す」他 5 項目、 介入 (2)では「資源ごみを持ち、回収ボックスに行く」 他 5 項目、介入 (3)では「カートを押す」他 3 項目を順 次導入した。P2 も同様であった。

フェイズごとに、母親と標的行動への支援について 打ち合わせを行った。おもな支援方法は、P1、P2 と もに言語指示や指さしであった。介入 (1) に導入した 標的行動の生起が安定し、母親の負担にならないこと を確認した上で介入 (2)に移行し、その後、介入 (3)、 介入 (4) (P2 のみ) に移行した。フォローアップでは、 P1で介入 (3)、P2で介入 (4)が終了した2 か月後に、同 店舗で標的行動の生起を確認した。

\section{6. 評価とデータの信頼性}

筆記記録とビデオ録画をもとに、標的行動の遂行レ ベルを自発遂行、母親のプロンプト、支援者のプロン プト、母親の遂行、機会なしの 5 段階で評価した。参 加児が一人で行ったことを自発遂行、母親が参加児に 声かけや指さしをしたり物を手渡ししたりする支援を 母親のプロンプト、支援者が参加児に声かけや指さし をする支援を支援者のプロンプトと定義した。

データの信頼性を査定するため、本研究に直接関与 しない大学院生 2 名と支援者が独立してビデオ記録を 視聴し、観察者間一致率を算出した。標的行動の生 起・非生起について、P1では BL と介入 (1)〜 (3)の各 フェイズで 1 セッショずつ計 4 セッション、P2でも 計 5 セッションを抽出し、3 名の記録が一致した標的 行動の項目数 / 全標的行動の項目数 $\times 100 （ \%)$ で算 出した。P1の一致率は、BLで 100\%、介入 (1)〜 (3)で $90.6 \%$ であったP2 の一致率は、BL で 100\%、介入
(1)〜 (4)で $90.4 \%$ と、いずれも $90 \%$ 以上で高い值で あった。

\section{7. 事後アンケート}

先行研究（神山・野呂, 2010; 竹井ら, 2009）を参照 し、介入終了後（フォローアップの前）、母親に買い 物指導に関するアンケートを依頼し、介入の効果や手 続きの社会的妥当性を評価した。参加児の様子（3 項 目)、指導効果の広がり（3 項目）、母親の支援に対す る意欲と負担感（11 項目）、きょうだい・家族への影 響（2 項目）、手続きの内容（12 項目）の計 31 項目を 設けた。「5：とてもそう思う」〜 1 : 全く思わない」の 5 件法で回答を求めた。

\section{III. 結 果}

\section{1. 標的行動の生起と遂行レベル}

（1）P1： Table 2 に、P1の標的行動の遂行レべ ルを示した。Table 2 より、介入 (1)では標的行動 1 5、介入 (2)では 6 10、介入 (3)では 11〜 13 を順次導 入した。BLの標的行動 1、4、5 の遂行レベルは母親 のプロンプトが多かった。標的行動 2、3 は、母親の 遂行が多かった。標的行動 2 「コバッグを開く」で は、介入 (1)で標的行動として導入したが、導入する 前のセッション 5 で自発遂行が認められ、その後、自 発遂行であった。標的行動 5 「エゴッグを持ち車に 運ぶ」では、BL と介入 (1)では母親のプロンプトで あったが、介入 (2)のセッション 8 より自発遂行が認 められた。標的行動 4 「かごを片付ける」では、セッ ション 9 で初めて自発遂行が認められ、セッション 15 以降、自発遂行が増加した。標的行動 3 「商品をエコ バッグに詰める」では、介入 (3)のセッション 13 と フォローアップのセッション 20 で自発遂行、その他 は母親のプロンプトであった。母親がかごの中にある 商品を指さしたり、商品名を教えると、順序よくエコ バッグに詰めることができた。

BL と介入 (1)の標的行動 6〜9 の遂行レベルは、母

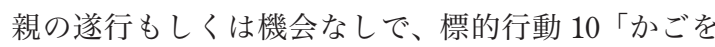
カートに置く」では機会なしであった。標的行動 6、 10 では、介入 (2)で導入後すぐに自発遂行で生起し た。標的行動 9 「紙パックを回収ボックスに入れる」 では、介入 (2)で標的行動として導入したが、導入す る前の介入 (1)のセッション 7 で母親のプロンプトで 生起した。セッション 11 で自発遂行が初めて認めら 机、セッション 15 以降、安定して自発遂行が認めら れた。

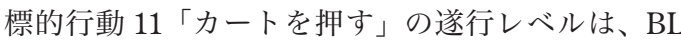


Table 2 P1 の標的行動の遂行レベル

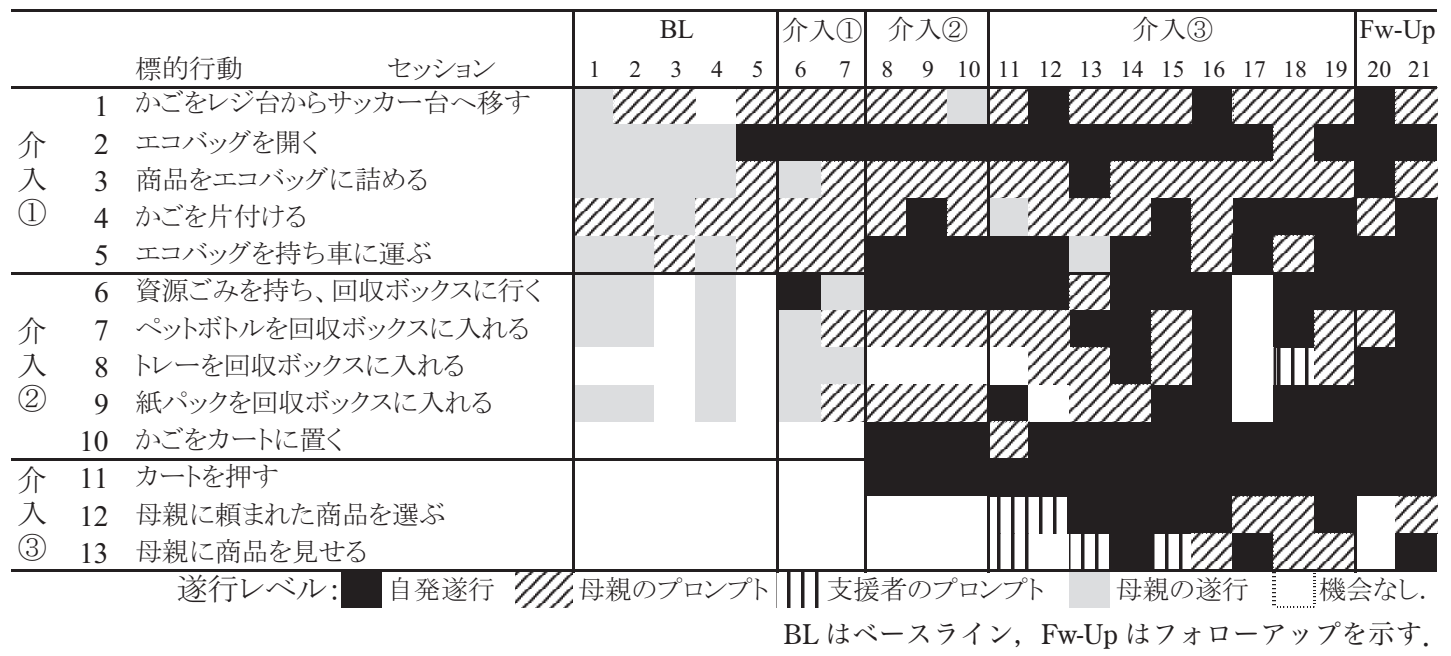

と介入 (1) で機会なしであったが、介入 (2) のセッショ ン 8 より自発遂行で生起した。標的行動 11 は介入 (3) で導入する予定であったが、介入 (2)で標的行動 10 「かごをカートに置く」を導入したことで、母親が自 発的にカートをP1に押させるようになった。その結 果、カートを押す行動は、介入 (2)のセッション 8 以 降、自発遂行が認められるようになった。標的行動 12、13 はBLと介入 (1)、介入 (2)で機会なしであった。 標的行動 $12 「 母$ 親に頼まれた商品を選ぶ」は、導入し た介入 (3)で、支援者が商品を指さすと、P1 は母親が 頼んだ商品を選ぶことができ、セッション 13 以降、 自発遂行が認められた。介入 (3) に導入した標的行動 $13 「$ 親に商品を見せる」では、支援者や母親の声か けによって選んだ商品を母親に見せることができ、 セッション 14、17、21で自発遂行が認められた。

介入 (3) 時のエピソード記録であるが、買い物が終 わり、車で家庭に帰った際、P1が自らエコバックを 持って家まで運び、その後母親の声かけを受けなが ら、買ってきた商品を冷蔵庫や棚に収める行動が何度 も認められた。それに対して、母親は「ありがとう」 「すごいね」と称賛していた。

( 2 ) P2 : Table 3 に、P2 の標的行動の遂行レベ ルを示した。標的行動 1、2、4 の遂行レベルは、BL で、母親のプロンプトもしくは母親の遂行であった。 標的行動 2 「商品をカートに入れる」では、介入 (1) で導入後すぐに自発遂行で生起した。標的行動 1 「商 品を取る」では、介入 (1)で導入してから自発遂行が セッション 8、15、20、21で認められた。標的行動
4「レジ袋を持ち車に運ぶ」では、介入 (1)で導入した 後、自発遂行は一度も認められず、母親のプロンプト が多かった。標的行動 3 「商品をもとに戻す」では、 BLで、母親の遂行もしくは機会なしであったが、介 入 (1)で標的行動として導入し、セッション 8 で母親 のプロンプト（指さし）によって商品をもとに戻すこ とができ、介入 (1)のセッション 10 で初めて自発遂行 が認められ、セッション 18 以降、自発遂行であった。 介入 (2) で設定した標的行動 5〜10 の遂行レベルは、 BL と介入 (1)では、母親の遂行がほとんどであった。 標的行動 9 「レジから出入り口までカートを押す」で は、導入した介入 (2)のセッション $11 \sim 13$ で母親の プロンプトであった。母親がカート前方をつかんで 誘導することで、カートを出入り口まで押すことが できた。介入(2)のセッション 14 で初めて自発遂行 が認められ、その後、自発遂行が増加した。標的行 動 6 「カートを押す」では、介入(2)の導入後、自発遂 行は一度も認められず、すべて母親のプロンプトで あった。

介入 (3) で設定した標的行動 11〜14 の遂行レベル は、BL〜介入 (2)で、母親のプロンプトもしくは母親 の遂行、機会なしであった。標的行動 11、13、14 は、 介入 (3) 以降、母親のプロンプトによる生起が安定し て認められた。標的行動 12 「ペットボトルを回収 ボックスに入れる」では、機会そのものが少なかつ た。介入 (4)で導入した標的行動 15～17 の遂行レベル は、BL〜介入 (3)では機会なしであった。標的行動 15 「母親に頼まれた商品のところへ行く」では、導入し 
Table 3 P2 の標的行動の遂行レベル

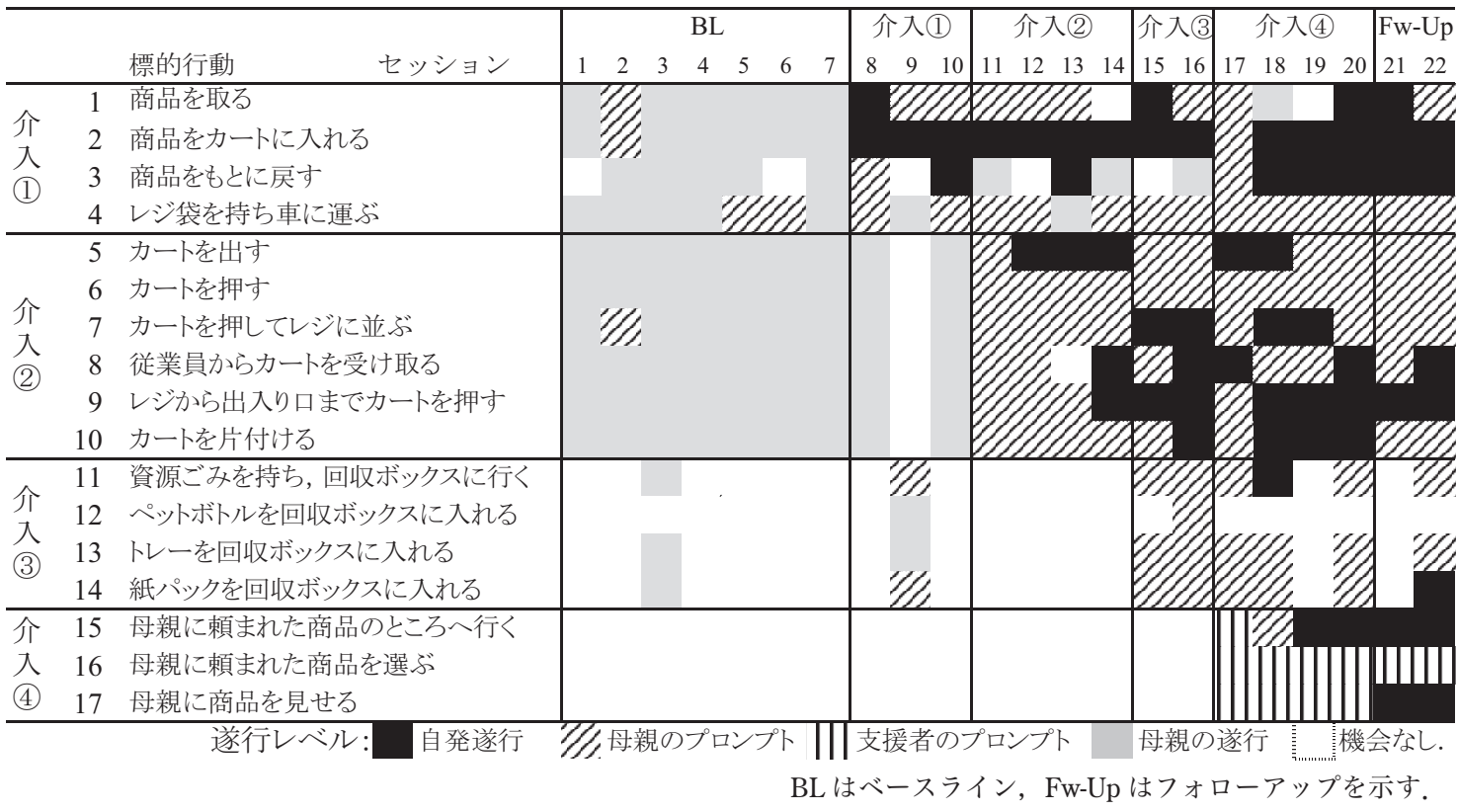

た介入 (4)のセッション 17 で支援者のプロンプトが認 められた。支援者が横に付いて促すと、商品のところ へ行くことができた。セッション 19 以降、自発遂行 が認められ、一人で商品のところに行くことはできた が、標的行動 16 「母親に頼まれた商品を選ぶ」では、 フォローアップの最後まで支援者のプロンプトであ り、指さしや声かけが必要であった。

P2 は、介入前は母親が買い物に誘っても同行せず、 外出には消極的で、自宅でテレビを見たりゲームをし たりして過ごすことが多かった。しかし、介入(3)、(4) では母親が買い物に出掛ける準備を始めると、自ら 「○○(P2の名前) も買い物いくー」と言い、買い物へ の同行を要求することがあったと母親は報告した。ま た、介入後、P2 はカートを押したり、商品を選ぶ役割 を与えられ、嬉しそうに母親とやりとりしながら遂行 し、店内での感覚遊びはみられなくなった。

\section{2. 事後アンケート}

Table 4 に事後アンケートの評価を示した。Table 4 より、参加児の様子では「お子さんは楽しんで買い物 している」でP1、P2 の母親ともに「5：とてもそう思 う」と回答した。母親の支援に対する意欲と負担感に ついては、「買い物は私一人で行ったほうが楽だ」で P1 の母親では「4:ややそう思う」 P2 の母親では 「5：とてもそう思う」であった。手続きの内容では、
「お子さんの目標は適切だった」で P1、P2 の母親とも $\ulcorner 4$ : ややそう思う」または「5：とてもそう思う」と回 答した。また、「お子さんに支援することで自分の買 い物が妨げられた」「段階的に目標を増やしていくこ とは負担だった」の項目では、「2：あまり思わない」 と肯定的な評価であった。

\section{IV. 考 察}

1. 生態学的調査にもとづく買い物行動の形成と参 加児の変容

本研究では、参加児に形成する買い物の標的行動の 選定にあたり、社会的比較の手続きによる生態学的調 查を実施した。調査結果より、同年代の子どもに多く 観察された「エコバッグまたはレジ袋を持ち車に運 ぶ」「カートを押す」「母親に頼まれた商品を選ぶ」行 動を、知的障害のある P1 と P2 の標的行動とした。こ れらの行動は、両児とも実態調査やBLでは、十分に、 または全く認められないものであった。しかし、介入 において段階的に導入したことで、P1 と P2 にとって 未経験の買い物行動を形成できた。

買い物行動の形成に伴う参加児の変容として、エピ ソード記録ではあるが、P1では、買い物が終わり車で 家庭に帰つた際、P1が自らエコバックを持って家ま で運び、その後母親の声かけを受けながら、買ってき 
Table 4 事後アンケートの評価

\begin{tabular}{|c|c|c|}
\hline 質問項目 & $\mathrm{P} 1$ & $\mathrm{P} 2$ \\
\hline \multicolumn{3}{|l|}{ 参加児の様子（3 項目） } \\
\hline お子さんは楽しんで買い物をしている & 5 & 5 \\
\hline 進んで買い物を手伝ってくれる & 5 & 5 \\
\hline $\begin{array}{l}\text { お子さんは自信を持って買い物をして } \\
\text { いる }\end{array}$ & 5 & 5 \\
\hline \multicolumn{3}{|l|}{ 指導効果の広がり（3 項目） } \\
\hline 買い物以外でも一緒に外出したい & 5 & 5 \\
\hline 家事も手伝って欲しい & 4 & 4 \\
\hline 自分で行動できることが増えている & 4 & 5 \\
\hline \multicolumn{3}{|l|}{ 母親の支援に対する意欲と負担感（11 項目） } \\
\hline 買い物へ一緒に行くことが楽しい & 5 & 5 \\
\hline 買い物を手伝ってくれることは助かる & 4 & 3 \\
\hline 今後も買い物を手伝って欲しい & 4 & 3 \\
\hline 店舗で行う手伝いを増やしたい & 4 & 3 \\
\hline 自宅での準備片付けを手伝ってほしい & 4 & 2 \\
\hline $\begin{array}{l}\text { 指導前と比べ、買い物時にお子さんの } \\
\text { 要望を取り入れている }\end{array}$ & 3 & 4 \\
\hline $\begin{array}{l}\text { 指導前と比べ、お子さんに商品を選ば } \\
\text { せている }\end{array}$ & 5 & 4 \\
\hline $\begin{array}{l}\text { 他のスーパーやコンビニで買い物をさ } \\
\text { せてあげたい }\end{array}$ & 3 & 4 \\
\hline $\begin{array}{l}\text { 雑貨店や衣料品店などで買い物をさせ } \\
\text { てあげたい }\end{array}$ & 4 & 3 \\
\hline 店舗での支援は負担だ* & 4 & 2 \\
\hline 買い物は私一人で行った方が楽だ* & 4 & 5 \\
\hline \multicolumn{3}{|l|}{ きょうだい・家族への影響（2 項目） } \\
\hline $\begin{array}{l}\text { 買い物指導は、きょうだいに良い変化 } \\
\text { を与えている }\end{array}$ & 3 & 2 \\
\hline $\begin{array}{l}\text { 買い物指導は、家族に良い変化を与え } \\
\text { ている }\end{array}$ & 5 & 4 \\
\hline \multicolumn{3}{|l|}{ 手続きの内容（12 項目） } \\
\hline $\begin{array}{l}\text { 定期的な面談では自分の要望が反映さ } \\
\text { れた }\end{array}$ & 4 & 5 \\
\hline お子さんの目標は適切だった & 4 & 5 \\
\hline $\begin{array}{l}\text { 目標を決める際に自分の要望が反映さ } \\
\text { れた }\end{array}$ & 4 & 5 \\
\hline 他の店舗でも進んで手伝ってくれた & 3 & 2 \\
\hline 目標を決める際の作業は面倒だった* & 2 & 2 \\
\hline 店舗でのビデオ撮影は苦痛だった* & 2 & 1 \\
\hline 自宅でのビデオ撮影は苦痛だった* & 2 & 1 \\
\hline $\begin{array}{l}\text { 買い物中に記録や指導をすることで周 } \\
\text { 囲のが気になった* }\end{array}$ & 2 & 1 \\
\hline $\begin{array}{l}\text { お子さんに支援することで自分の買い } \\
\text { 物が妨げられた* }\end{array}$ & 2 & 2 \\
\hline 買い物の記録は負担だった* & 2 & 1 \\
\hline $\begin{array}{l}\text { 段階的に目標を増やしていくことは負 } \\
\text { 担だった* }\end{array}$ & 2 & 2 \\
\hline $\begin{array}{l}\text { 他の店舗では指導したことができな } \\
\text { かった* }\end{array}$ & 2 & 4 \\
\hline
\end{tabular}

5：とてもそう思う，4：ややそう思う，3：どちら でもない，2：あまり思わない， 1 : 全く思わない.
た商品を冷蔵庫や棚に収める行動が何度も認められ た。P2 では、母親が買い物に出掛ける準備を始める と、自ら「○○(P2の名前) も買い物いくー」と言い、 買い物への同行を要求することがあった。P2 はカー トを押す、商品を選ぶ役割を与えられ、嬉しそうに母 親とやりとりしながら遂行していた。こうした参加児 の望ましい変容、つまり買い物への積極的な姿勢は、 生態学的調查にもとづく標的行動の選定が適切であっ たことを示している。本研究の結果より、知的障害の ある子どもの標的行動を選定する際、社会的比較によ る同年代の子どもを対象とする生態学的調査が有効で あり、先行研究（渡部ら, 1999）のように参加児と家 族対象の実態調査のみでは不十分であることが指摘で きる。

次に、生態学的調査より形成した P1 と P2 の標的行 動「エコバッグまたはレジ袋を持ち車に運ぶ」「カー トを押す」「母親に頼まれた商品を選ぶ」行動が生起 した要因や指導上の課題について考察する。

標的行動（P1で 5、P2で 4)「エコバッグ（P2 でレ ジ袋）を持ち車に運ぶ」の遂行レベルは、P1、P2 とも に、介入 (1)の導入後すぐに母親のプロンプトで生起 した。BLでは母親の遂行が多かった。この標的行動 は、生態学的調査で頻繁に観察され、実態調査では $\mathrm{P} 1 、 \mathrm{P} 2$ ともに 1 回のみ観察されていた。P1、P2 とも に、介入前からエコバッグを持って車に運ぶ行動その ものは有していたと推測される。しかし、実態調査や BLでは買い物行動として定着していなかった。参加 児がすでに有する行動と予測し、介入 (1)で標的行動 として導入し、生起機会が与えられたことで、導入後 すぐに生起したと考えられる。標的行動となったこと で、母親はエコバッグを持って運ぶ機会を確実に提供 するようになった。

標的行動（P1で 11、P2 で6）「カートを押す」では、 P1では標的行動として導入する以前の介入 (2)より 自発遂行が認められた。P2では標的行動とした介入 (2)より母親のプロンプトによる遂行が認められた。 この標的行動は、P1、P2 ともに、実態調査では一度も 観察されなかった。しかし、生態学的調査より、カー トを押す行動は同年代の子どもで多く観察されたこと から、母親に提案し、取り組んだ。P2ではカートを押 す行動は初めての経験であったが、カートのような物 品を押したり引いたりする行動は学校や家庭での先行 経験があり、行動レパートリーを有していたと考えら れる。実際、大学での指導場面では教材の準備や片付 け時に何度も観察されていた。買い物時における参加 
児の直接的な経験がなくても、生態学的調査から取り 入れ、参加児がすでに有する行動を標的としたこと で、導入後すぐに生起したと考えられる。生態学的調 査により参加児の未経験の行動を標的とする場合、他 の生活場面で先行経験や行動レパートリーを有してい るかどうかが要点になると考えられる。

カートの使用について、実態調査では、P1の母親は 商品の陳列棚や他の客にぶつかることを不安視し、P1 にカートを押させることはなかった。そこで介入 (2) でカートを押す行動を導入する準備として、標的行動 10「かごをカートに置く」に取り組んだ。この標的行 動の支援を開始すると、母親は自ら P1 にカート置き 場からカートを出すことを指示し、カートを押す行動 を促すようになった。結果として、P1 は陳列棚や他 の客にぶつかることなくカートを押すことができた。 母親がカートを押す行動に自発的に取り組んだ理由と して、最初の介入 (1)において声かけや指さしの簡単 な支援によってP1の標的行動が生起するという成功 体験が関与している可能性を指摘できる。支援をする と子どもが買い物を手伝ってくれるという介入 (1)で の成功体験がその後の母親の支援行動を強化し、カー トを押す行動への支援につながったと推測されるが、 母親の成功体験と支援行動との関連の検証は今後に残 された課題である。

標的行動（P1で 12、P2で 16）「母親に頼まれた商 品を選ぶ」では、介入 (3)、介入 (4)で導入した直後に、 母親や支援者のプロンプトで生起した。生態学的調査 では、同年代の子どもが母親と店内で別行動をとり、 母親が頼んだ商品を探しに行ったり選んだりする行動 が多く認められた。この行動は P1、P2 ともに全く経 験がなく、難易度も高く、時間を要すると予測され た。実際に取り組むと、P1では導入後すぐに支援者の プロンプトで生起し、後半で自発遂行も認められた が、P2では最後のフォローアップまで自発遂行はな く、支援者のプロンプトが必要であった。P2では P1 に比べて検査結果の $\mathrm{SA}$ や SQ 值は低く、学習や他者と のやりとりスキルは十分でなく、母親が頼んだ商品を 数多くある商品から選ぶことが難しかった。母親は P2 から離れて移動していたために支援が難しく、 フォローアップまで支援者の声かけや指さしが必要で あった。「母親に頼まれた商品を選ぶ」では、子どもは 母親の言語指示した商品名を短時間記憶し、移動し て、棚に置か水た数多くの商品からマッチングして選 び取る一連の行動連鎖が必要となる。これらの行動連 鎖を助けるためには、商品の写真カードを付加する、
商品名をメモするといった支援の付加が必要であった と考えられる。

\section{2. 標的行動選定の観点と手順の妥当性}

生態学的調査にもとづく標的行動を含めて最初に抽 出した候補は、P1 727 項目、P2 256 項目もあり、 すべてを一度に標的行動とすることは支援者である 母親の負担が大きく、適当ではなかった。そこで、 Table 1 に挙げた先行研究で示された観点をもとに評 価し、優先順位を付けると、介入ごとに 3〜 項目に 絞り込めた。売り場やレジなどの場面で分類し、参加 児が容易にできそうな項目が多くある場面を優先して 介入 (1)〜 (4)で段階的に導入した。こうした場面ごと に一連の標的行動を段階的に導入する手続きによつ て、母親はどの場面で参加児の買い物行動を支援すれ ばよいかが理解しやすかったと考えられる。P1、P2 ともに、事後アンケートでは肯定的な意見が多く、母 親の支援に要する負担は全体的にみると少なかったと いえる。P1、P2 の母親ともに、「段階的に目標を増や していくことは負担だった」「お子さんに支援するこ とで自分の買い物が妨げられた」に対して「あまり思 わない」と回答した。これらの結果より、本研究で害 施した標的行動選定の観点と手順、母親の負担を考慮 した段階的な導入が適切であったと考えられる。

標的行動の選定にあたり、「参加児が実行できる （すでに有する）スキルか」「母親の支援に要する負担 があるか」の観点は重要であった。それに対して、 「参加児の興味、関心に合っているか」「母親は参加児 のスキル獲得によって助けられるか」「母親の買い物 スタイルに近いか」「その行動を参加児が遂行するこ とで母親が助けられる」の観点では、それらを満たさ ない行動でも、母親が支援することで標的行動の生起 が認められた。一例を挙げると、「参加児の興味、関 心に合っているか」では、実態調査で、P2 は店内でブ ロック玩具での感覚遊びに従事しており、買い物への 興味、関心が低かったと思われる。介入では、母親が 遂行機会を与えたことで買い物行動が生起するように なり、P2 はカートを押す、商品を選ぶ役割を与えら れ、嬉しそうに母親とやりとりしながら遂行し、店内 での感覚遊びはみられなくなつた。これらの結果は、 参加児の興味、関心の低い標的行動でも、母親の支援 付きで十分に形成可能であることを示唆している。母 親は事後アンケートで「P2 が楽しんで買い物をして いる」と回答した。一方で、「買い物は私一人で行った ほうが楽だ」では、P1の母親は「ややそう思う」、P2 の母親は「とてもそう思う」と評価し、参加児の同行 
が重荷になる状況も部分的に窺えた。日常の買い物中 に参加児への支援を行ったため、介入前よりも多くの 時間を要したことが理由と考えられる。社会的比較に よる生態学的調查にもとづき、参加児にとって経験の 乏しい標的行動の形成に積極的に取り組み、知的障害 のある子どもと母親の両者が成功体験を得て、次のス キル形成の励みとなるような手続きの追求が今後も必 要である。

\section{文 献}

安部博志 (1997) 自閉症児の社会生活スキル訓練一一 人通学の訓練プログラムの検討一. 特殊教育学研 究, 34(5), 117-123.

福永 顕・大久保賢一・井上雅彦 (2005) 自閉症生徒 における携帯電話の指導に関する研究一現実場面一 の般化を促す指導方略の検討一. 特殊教育学研究, 43, 119-129.

原野明子 (1997) 事象見本法の理論と技法. 中澤 潤・ 大野木裕明・南 博文 (編), 心理学マニュアル観察 法. 北大路書房, 24-35.

岩嶋利恵 (2008) 知的障害児の家族のライフスタイ ルに適合した協働的な取り組み. 発達障害研究, 30 , 322-327.

神山 努・野呂文行 (2010) 発達に障害がある児童・ 生徒における地域・家庭生活スキルの日常生活への 自発的開始・般化の検討一保護者による記録に基づ いた保護者支援による介入一. 特殊教育学研究, 48 , 85-96.

加藤哲文 (1997) コミュニケーション行動を形成する ための基礎的・応用的指導技法. 小林重雄 (監修), 山本淳一 - 加藤哲文 (編), 応用行動分析学入門. 学 苑社, 97-120.

小貫 悟 (2009) LD・ADHD・高機能自閉症へのライ フスキルトレーニング. 日本文化科学社.

Morse, T. E., Schuster, J. W., \& Sandknop, P. A (1996) Grocery shopping skills for persons with moderate to profound intellectual disabilities: A review of the literature. Education and Treatment of Children, 19, 487-517.

野呂文行（1996）コミュニケーション行動の查定方 法. 小林重雄 (監修), 加藤哲文・山本淳一 (編著), 応用行動分析学入門. 学苑社, 139-158.

太田有紀 (2014) 広汎性発達障害児の家庭生活スキル の形成. 上越教育大学大学院特別支援教育コース修 士論文.

嶋田あおい・清水直治・氏森英亞（1998）ダウン症生 徒におけるビデオモデリングを用いた買物スキルの 形成に関する検討. 行動分析学研究, 13, 27-35.

菅野千晶・羽鳥裕子・井上雅彦・小林重雄（1995）自 閉症生徒の買物指導と日常生活における般化および 維持に関する検討. 特殊教育学研究, 33(3), 33-38. 竹井清香・五味洋一・野呂文行 (2009) 機能的アセス メントに基づく自閉症スペクトラム幼児とその母親 に対する家庭内支援一注目によって動機づけられた 行動問題への効果一. 障害科学研究, 33, 13-24.

渡部匡隆・山口とし江・上松 武・小林重雄 (1999) 自閉症児童における代表例教授法を用いた支払いス キルの形成一複数店舗への般化の検討一. 特殊教育 学研究, 36(4), 59-69.

渡部匡隆・山本淳一 - 小林重雄 (1990) 発達障害児の サバイバルスキル訓練一買物スキルの課題分析とそ の形成技法の検討一. 特殊教育学研究, 28(1), 21-31. 依田雅美・清水直治・氏森英亜（1996）精神遅滞児に おける買い物スキルの形成と般化に関する研究一実 際場面とシミュレーション場面での訓練の分析一。 行動分析学研究, 9, 22-28.

横浜市こども青少年局横浜障害児を守る連絡協議会 （2011）障害児と家族の生活状況調査報告書一アン ケート集計結果と分析一. 横浜市こども青少年局報 告書, 2011 年 4 月 1 日, http://www.city.yokohama.lg.jp/ kodomo/kikaku/syogaijichosa/file/houkokuzennbun.pdf (2013 年 9 月 1 日閲覧).

-2018.2.1 受稿, 2018.10.27 受理一 


\title{
Practical Research
}

\section{Using an Ecological Inventory to Identify Purchasing Skills to be Shaped: Children With Intellectual Disabilities}

\author{
Emi YokOYAMA* and Tomohiko MuranaKA** \\ * Koide Special School for Children with Special Needs \\ (Uonuma, 946-0035) \\ ** Clinical Psychology, Health Care and Special Needs Education, \\ Joetsu University of Education \\ (Joetsu, 943-8512)
}

\begin{abstract}
The present study aimed to modify the purchasing skills of 2 students with intellectual disabilities when they shopped with their mother, using an ecological inventory and social comparison to identify needed skills, and examining factors that may affect their shopping behavior and changes in their behavior. The participants were 10-year-old girl and an 8-year-old boy, both with intellectual disabilities. Initially, their viewpoints and the validity of the procedures were used to select the target behavior, i.e., purchasing skills. The intervention was conducted in a local grocery store. Before the intervention, an ecological inventory was used to identify the purchasing skills of other children at those ages. As a result, the target list for the girl's purchases contained 13 items, and the boy's list, 17 items. After baseline measurements, the intervention was implemented for several of the target behaviors, step by step. After the intervention was concluded, follow-up sessions were held. The results showed that the level of spontaneous performance increased in the latter half of sessions or immediately following an intervention session. These findings suggest that behavior that the participants had not previously shown could be shaped by an intervention based on a plan developed through an ecological inventory. It is possible that the children's mothers felt success as a result of the participants having acquired new purchasing skills.
\end{abstract}

Key Words: ecological inventory, purchasing skills, children with intellectual disabilities 